\title{
From 'Shallow' to 'Deep' Policing: 'Crash-for-Cash' Insurance Fraud Investigation in England and Wales and the Need for Greater Regulation
}

\author{
Mark Button\# and Graham Brooks \\ \#Corresponding author: mark.button@port.ac.uk \\ \#Centre for Counter Fraud Studies, University of Portsmouth, Portsmouth PO1 2HY. \\ Centre for Research in Law, University of Wolverhampton.
}

\begin{abstract}
The policing of insurance fraud has traditionally been dealt with beyond the criminal justice system as a private matter between the claimant and the insurer with only a few iconic cases referred to the criminal justice system each year. The growth of insurance fraud, particularly 'crash-for-cash' fraud, and the disinterest of the police, has led to a change in the response of the insurance industry. This paper will argue this response can be characterised as a shift from the traditional 'shallow' to a 'deeper' form of policing which sees greater focus upon criminal and quasi-criminal outcomes. This paper explores some of the private and innovative methods the industry has developed and illustrates at a time when police privatisation has become a higher profile issue what greater private criminal investigation might look like. The paper argues the shift to 'deeper' policing necessitates greater regulation of the private investigation of crime and outlines a number of proposals to address this gap which require further consideration and debate.
\end{abstract}

Key words: private investigation, insurance fraud, 'shallow' and 'deep' policing, privatisation

\section{Introduction}

Private policing is a serious subject in criminology attracting the attention of many significant scholars (Shearing and Stenning, 1987; South, 1988; Johnston, 1992; Jones and Newburn, 1998; Loader, 2000; Prenzler, 2006). Research on private policing, however, has tended to focus largely upon the private security industry. There is also hybrid, voluntary and other private contributions to policing (Johnston, 1992). This paper will focus upon the private contribution to the policing of insurance fraud, which covers the in-house capacity of insurance companies as well as contract private investigation and the legal and consultancy practices that provide policing services to insurance firms. Insurance fraud is a crime which traditionally in England and Wales has been settled between the claimant and insurer with little involvement of the criminal justice system by the insurance companies own counter fraud infra-structure, along with various types of private contractors (Clarke, 1989). The insurance sector makes for an interesting case study, when privatisation and responsibilization are so high on the agenda in England and Wales (Holliday, 2000; Jessop, 2004; Ilcan and Basok, 2004; Kemshall, 2008; Levi and Maguire, 2012). The latter which involves the state increasingly seeking to encourage non-state actors in crime prevention through partnerships (Crawford1998; Bottoms et al, 2001), multi-agency groups (Hughes and Edwards, 2002); and activating communities, '... to devolve responsibility for crime prevention on to agencies, organizations and individuals which are quite outside the state and to persuade them to act appropriately', the policing of insurance fraud would be a contemporary example (Garland, 1996: 452). Insurance fraud has been a crime in the past traditionally dealt with largely by the industry 
without state help - a model for the current coalition government looking to showcase the private sector taking care of a crime problem. Much of the policing historically (and still to a large extent today) centred round strategies to repudiate fraudulent claims, with the very rare involvement of the police and the criminal justice system (Clarke, 1989). Private policing still dominates today, but the orientation of these structures is changing. The private investigation sector has also been the subject of limited research (Gill and Hart, 1997; Prenzler, 2006).

This paper will argue there is a distinction between 'shallow' and 'deep' policing. The former encompasses deviant acts of fraud, which could be dealt with through the criminal justice system if the insurer wanted but instead are largely settled outside the criminal justice system between the insurer and the claimant (Reichman, 1987; Clarke, 1989). The essence of 'shallow policing' is therefore the pursuit and settling of deviant acts without recourse to formal state or quasi-state structures (criminal justice system, civil justice system, regulatory bodies and non-statutory sanctions of industry funded bodies), where the consequences of proof of fraud are the repudiation of the claim, possibly the refusal of cover and/or future higher premiums. The purpose of the investigation is to confirm or repudiate a claim and the consequences of the investigation rarely have implications beyond that particular claim. By contrast 'deep' policing involves these strategies combined with the development of more police-like institutions and practices where outcomes start to move more frequently toward quasi-criminal and criminal sanctions. It represents a 'netwidening' where more dishonest claimants will be brought into the criminal and quasi-criminal justice system (some of the quasi-criminal sanctions will be introduced later in this paper) (Cohen, 1985) and a form of actuarial justice (Feeley and Simon, 1994). Figure 1 illustrates the range of shallow to deep policing. Thus burglary would be an example of deviant act largely dealt with at the 'deeper' end of policing, where insurance fraud traditionally would have been 'shallow'.

Figure 1 about here.

The involvement of organisations in what this article will argue is the 'shallow end' of policing is uncontroversial to most. However, the traditional paradigm of the policing of insurance fraud has come under severe pressure with the growth in insurance fraud and particularly organised insurance fraud related to 'cash-for-crash' fraud. More broadly there has been a growing realisation of the substantial cost of insurance fraud to insurers and consumers (who pay with higher premiums), the involvement of organised crime, as well as the consequences of some of these frauds, particularly 'crash-for-cash', where there have been dozens of innocent motorists suffering trauma and injuries, and even a fatality, as a consequence of the fraud. (1) These have contributed to influence many company and industry initiatives towards the policing of insurance fraud into 'deeper' policing. This has involved the creation and pursuit of quasi-criminal sanctions, more criminal prosecutions and the embracing of various policing techniques associated with mainstream criminal investigation, such as intelligence databases and surveillance. The consequences of these changes are likely to see more 'net-widening' beyond organised fraudsters.

These changes have been occurring against a backdrop of the potential privatisation of a variety of police functions in England and Wales, which have proved very controversial. (2) One of the functions which caused some of the most controversy is criminal investigation (Pearse, 2012). Given what is incrementally emerging in the insurance sector, this provides interesting clues to what 
greater private sector involvement in criminal investigation may look like and some of the challenges and policy implications this has. This paper will outline the evidence for a shift from 'shallow' to 'deep' policing for insurance fraud using largely 'cash-for-crash' fraud, but with some reference to more general insurance fraud. It will review the nature of 'cash-for-crash' fraud, the challenges this has posed for insurers, before examining the 'deepening' involvement of the private sector. The paper will end by examining some of the implications of these changes and areas in need of reform as a consequence. Before we embark upon this, however, the methods for this research will be outlined.

\section{Methods}

This paper draws upon part of the findings from a research project funded by Acromas (which owns the insurance groups Saga and the AA) into 'crash-for-cash' fraud in 2011-12. The aims of the research covered two broad areas. The first related to the effectiveness of strategies used by those bodies countering this type of fraud. The second related to understanding the motivations and modus operandi of the actual fraudsters. To undertake the research three broad strategies were pursued: desk based research, interviews with stakeholders and interviews with fraudsters who have been involved in this type of fraud. This paper is largely drawn from the research related to the first set of aims and the desk based research and interviews with stakeholders. The interviews and data related to the actual fraudsters will form a separate paper to be developed later. The search of databases of research, news items and the websites of relevant bodies produced data on cases, strategies, tactics of insurance bodies and law enforcement, some of which will be developed in this paper. Eight stakeholders with an interest in this problem were also interviewed. These included: two police detectives who had been involved with 'crash-for-cash' frauds, the Director of the Insurance Fraud Bureau, two solicitors who have dealt with cases in this area as well as a paralegal, a commercial private investigator specialising in insurance fraud and a civil servant from the Claims Management Regulator (this regulates claims management companies, some of which have been involved in 'farming' fraudulent insurance claims). The research also generated ideas and issues of concern for the researchers beyond the remit set by Acromas, which will also be developed throughout this paper, particularly towards the end.

\section{'Cash-for-Crash' Fraud in Context}

'Cash-for-crash' fraud is based upon some form of deception relating to an insurance claim for a motor accident. There are a number of variations on this scam which are listed below.

\section{The exaggerated claim}

In this type of fraud a real accident takes place, but it is used to submit exaggerated claims. This is usually undertaken by opportunistic fraudsters who didn't crash deliberately, but rather presented with the opportunity of the accident decide to take advantage of it by inflating damages, making up or exaggerating personal injuries (particularly whiplash), exaggerating the impact on loss of earnings and claiming for additional passengers.

\section{The induced accident}

In this type of fraud the aim is to target a vehicle, which is likely to have insurance such as older people, a commercial van or lorry, and then engineer an accident where it will be their fault so as to 
make claims against their insurance. One of the most common approaches is to use a roundabout and then put on breaks suddenly (with disconnected break lights) and the innocent party crashes into the back. A further technique is to gradually use the hand-break to slow the car, which does not activate the break-lights. The crash then enables numerous claims to be made against the innocent driver's insurance. These are also known as 'slam ons' and 'rear ending'.

\section{The staged accident}

This is where both drivers know one another and they stage an accident with the view to making multiple claims. In this version of the scam they actually go out on the roads and deliberately crash.

\section{The fictitious staged accident}

This is a variation on the above, but in this one the accident does not take place, instead the vehicles are damaged to make them look like they have been involved in an accident, but the actual damage is done off road by crashing other vehicles into the car, hitting it with sledge hammers or JCBs. Again multiple claims are then made as a result of the 'accident'.

\section{The fictitious paper accident}

The final variation is where there is no accident at all, but paperwork is submitted stating that there was an accident and the multiple claims are made. This type may involve deliberate damage to vehicles being undertaken, not necessarily in an accident, but if the insurer wants to see evidence.

More recently a variation on the 'crash-for-cash' has emerged which has been dubbed 'flash-forcrash'. Under this variation the fraudster 'flashes' the headlights of his/her to a car seeking to exit a junction to coax them out and then deliberately continues, crashing into the duped car. The victim then faces the difficult task of proving that the oncoming car 'flashed' their lights to encourage them out.

To the lay observer it may seem strange how money can be made from deliberate crashes. There are, however, a variety of income streams which can be pursued once a 'crash' has taken place.

- Cash for damage to a car or completely new car from insurers.

- Personal injury claims for whiplash injuries for those 'in the vehicle'. Often there will be more than one person in the car or at least the claim will say there is more than one.

- Claims for loss of earnings

- Cost of hire cars

- Fees for accident management companies

- Fees for those recovering, storing or repairing the vehicle

- Fees for solicitors

- Fees for doctors

The amount of money that can be made from one accident could be between $£ 3 k$ and $£ 30 k$. Those engaged in this fraud range from opportunistic ordinary and generally law abiding citizens who then seize the opportunity to exploit a real accident or fabricate one, to families to organised criminals. For example in March 2013 the trial process ended for a total of 60 people from County Durham associated to a notorious crime family the 'Wrights' in Burnhope who were linked to over 250 
suspicious accidents and convicted for over half a million pounds of fraud (The Guardian, 2013). At the other end of the spectrum Joanne Kirk was found guilty of Contempt of Court related to an exaggerated personal injury claim for a rear end shunt she had experienced and received $£ 25,000$ compensation for (Guildhall Chambers, n.d.).

The extent of 'crash-for-cash' fraud was illustrated by an Insurance Fraud Bureau report in 2013 which estimated this type of fraud is worth $£ 392$ million and that 1 in 7 personal injury claims are linked to 'crash-for-cash' scams, which amounts to 69,500 claims (Insurance Fraud Bureau, 2013). The report also noted 1 in 10 would consider taking part in such a scam. Central to the 'crash-forcash' scam is a personal injury claim and frequently this centres on whiplash. The House of Commons Transport Committee has conducted several inquiries into motor insurance and has touched upon the issue of fraud. It published some interesting statistics on the rise in personal injury claims set against the number of casualties on roads. They showed while road casualties falling between 2005-10 from over 270,000 to just over 200,000, the number of motor insurance injury claims rose from just over 466,000 to over 790,000 (House of Commons Transport Committee, 2011).

Figure 2 about here.

The House of Commons Transport Committee (2011) estimated 70 percent of personal injury claims are for whiplash, which is very hard to prove medically. Jack Straw MP in evidence to the committee described whiplash as,

not so much an injury, more a profitable invention of the human imaginationundiagnosable except by third-rate doctors in the pay of the claims management companies or personal injury lawyers (House of Commons Transport Committee, 2011: 7).

Indeed research published in 2013 by the Association of British Insurers found the UK was the whiplash capital of Europe. It found that 78 percent of personal injury claims following accidents are for whiplash. This compares to 30 percent in France and Denmark, 31 percent in Spain, 35 percent in the Netherlands and 68 percent in Italy (Association of British Insurers, 2013). The same report also found motor whiplash claims cost $£ 2.2$ billion annually adding $£ 90$ to the average premium. Given this context it is not surprising to find the Insurance Fraud Bureau (IFB) estimating there are over 60,000 high risk networks focused upon this scam. The reasons for the growth of such claims is beyond the scope of this paper but briefly some of the reasons which have been identified include: the advent of no-win-no fee arrangements for lawyers, the growth of claims management companies and the growth of referral fees.

\section{The Challenge of 'Crash-for-Cash' Fraud for Insurers}

The size of the problem has been clearly illustrated in the section above. The dangers posed to the public from motor accidents, the large amounts of money at stake, combined with the involvement of organised criminals would lead many to think the police would take an active interest in this crime. Unfortunately this is not the case, which is familiar for a wide a rage of other frauds too (Brooks and Button, 2012; Doig and Levi, 2013). The ABI submission to the 2006 Government Fraud Review highlighted significant police disinterest in major organised 'crash-for-cash' fraud. One case illustrated in the submission involved $400+$ staged accidents involving organised criminals, who were 
using the money to fund drug-trafficking, prostitution and gun running the police would only investigate if the insurers funded it. As a result this case did not go any further (Association of British Insurers, n.d.). Other cases like this were also cited. Indeed one of the conclusions in this submission was:

Most police forces do not have the resources to deal with fraud effectively. There is a shortage of experienced fraud officers, and those few with the right experience are frequently transferred to other duties. Even where dedicated financial crime units exist, their main role is to support other officers on technical issues (such as tracing money and asset recovery) arising from more "conventional" crimes ( $p$ 5).

When the police have become involved in the investigation of 'crash-for-cash' fraud it has often been by accident where they have been pursuing an organised crime group and found evidence of this crime and used this as the best way to pursue them, rather than an interest in 'crash-for-cash' fraud. For example one police officer interviewed for this research stated:

It was in the middle of May 2006 we were looking at an organised crime group to establish what criminality they were involved in, erm, and from looking at the observations material... Those observations showed a lot of vehicles being bought onto \#\#\#. Towards the end of the second period of observations the person who, who lived at the farm, a gentleman called \#\#\#\#, was seen to - by the observation officers - to damage the front of a Jaguar motor vehicle with a JCB bucket. And it ... really this was, erm, you know, I suppose you could call it their Achilles heel because, erm, no-one expected it to be "Cash for Crash" and it was only as a result of \#\#\#\# hitting the front of this JCB, hitting the front of the Jaguar with a $J C B$, that we started an investigation into why that had happened and very quickly established that, erm, allegedly, a number of days earlier, the Jaguar had hit the gates at \#\#\#\# causing damage to $f 15,000$ worth of gates... So that started the ball rolling with, erm, "Cash for Crash" investigation.

Insurers in the absence of sufficient police support to pursue fraudsters have had to develop their own capacity within insurance companies, across the industry and purchase services from a range of different private organisations (Doig and Levi, 2013). As this will show, this has involved a 'deepening' of their involvement in policing.

\section{The 'Deepening' Involvement of the Private Sector}

Traditionally the insurance sector has taken care of the problem of fraud with very little reference to the police and criminal justice system. As Clarke (1989: 16) noted in the late 1980s:

Insurers, moreover, are not especially interested in persuading the police, in particular, to take an active interest. Insurance is regarded as a private contract between insurers and insured; even if criminal fraud is committed, the tendency of insurers is to deal with the matter themselves unless there is clear evidence for prosecution, in which case it is passed to the police for effective action...

He goes on to argue, 
Adjusters, who are in the front line in this respect, are specifically instructed that, if evidence of a criminal offence is uncovered in their inquiries, they have an obligation to disclose it to their principals but not to act as an informant to the public authorities...

This paper has shown that the increase of 'crash-for-cash' insurance fraud (and others too), combined with police indifference has created a challenge for the insurance industry. This has culminated in a variety of initiatives some of which mark a shift from this traditional 'shallow' policing towards the 'deeper' policing.

Insurers have developed their own infra-structures to tackle the problem of insurance fraud. These vary from insurer to insurer but can largely be grouped under the following categories. Claims handlers are the front-line staff dealing with insurance fraud. They deal with an initial claim and identify any which are higher risks. Some firms have specialist claims handlers for higher risk claims. In some cases these are carried out by specialist contractors. Many firms have an in-house investigative capacity to investigate high risk claims. Some of these firms also make use of contract investigators for specialist work such as surveillance; others contract out most of the investigative work. Loss adjusters also become involved in fraud investigations too, although these tend to be used in higher value cases (Clarke, 1989; Morley et al 2006; Smith et al 2010).

The contract sector supporting investigations is rooted in specialist investigatory firms, loss adjusters, general firms of private investigators and legal practices offering multiple services. One of the largest providers of investigatory services is G4S Investigatory Services. This was established in 2011 with the acquisition of the Cotswold Group, which had been the largest provider of investigatory and surveillance services to the insurance industry. Insurance fraud related to motor accidents has been a particular area of specialism for this company. G4S has one of the largest databases of intelligence relating to 'crash-for-cash' fraud using i2, which is a software application developed for the FBI. In 2009 over 2 million entries were held on the database relating to fraud from names to mobile phone numbers. Each day insurers subscribing to their services wash their data from new claims through their database to look for potential risks which may trigger an investigation. If there is an investigation this might involve staff interviewing claimants as well putting them under surveillance. In 2011 the Cotswold Group estimated the contracted motor insurance fraud investigation market alone was worth $f 30$ million per year and at the time they had a $£ 12$ million share (this excluded loss adjusting and legal).

There are also firms of solicitors in the market who offer a joined up investigation and legal service. One of the most prominent is Keoghs. It offers a range of services to the insurance industry, one area of which is fraud, with a particular focus on 'crash-for-cash' related fraud. The division dedicated to fraud started in 1997 with two people, which by 2011 had grown to 200+. Insurers will outsource suspect claims to them and Keoghs will deal with the processing of that claim including the investigation of it as well as any associated legal issues.

Insurers have also indirectly benefited from the growing range of surveillance tools which cover the United Kingdom, most notably CCTV. This tool can be found on many public roads, private car parks as well as private spaces. Frequently in investigations of claims it is possible to secure video footage to confirm or repudiate the statements of claimants. For example in 2011 a woman who had claimed she suffered whiplash as a result of a crash with a bus was exposed as a fraud when access to the bus onboard CCTV showed she was actually out of the car on the opposite side of the road when the 
bus hit her car. She was found guilty of fraud and given a 12 month community discharge (Metropolitan Police Service, 2011). CCTV and associated tools such as Automatic Number Plate Recognition (ANPR), combined with the growth of social networking websites such as Facebook, where claimants (or friends of them) sometimes publish details of their lifestyle which contradict their claims (such as pictures of playing football when a claim states they can hardly walk), have all combined to aid investigators in validating claims.

\section{Industry responses}

The insurance industry has also realised it needs to work together to tackle the problem of fraud. The first stage of response to the growing problem of insurance fraud has been various cross-sector systems of information exchange. In 1994 The Claims and Underwriting Exchange was created which has details of all incidents reported to insurance companies relating to motor, home, personal injury and industrial accidents. It has millions of records and enables insurers to check claims to see if the claimant has made previous claims and disclosed them (The Claims and Underwriting Exchange, n.d). In addition to this database there are also The Motor Insurance Anti-Fraud and Theft Register, which contains numerous details concerning vehicles, from mileages to those stolen or written off after an accident (Motor Insurance Anti-Fraud and Theft Register, n.d.). Additionally there is The Motor Insurance Database which holds data on all insured drivers (including named drivers) enabling checks to be made on motor insurance holders (Motor Insurers Bureau, n.d.).

The growth in the challenge of insurance fraud combined with the failures of the statutory policing infra-structure to adequately deal with the problem of insurance fraud in general has led to a number of significant industry initiatives to further build their own private policing infra-structure. In 1999 an informal network of insurance fraud investigators was formalised into the Insurance Fraud Investigators Group (IFIG), which now has over 320 member organisations and has achieved 'Specified Anti-Fraud Organisation Status' under the Serious Crime Act 2007. IFIG's main activity is operating a database of intelligence on insurance fraud which adheres to the National Intelligence Model. Insurers and public sector law enforcement place intelligence on this database enabling them to share this. IFIG with its replication of state centred model of intelligence sharing has represented a step towards 'deeper' policing for insurance fraud.

To further enhance information sharing and to strengthen the industry response to organised fraud in 2006 the Insurance Fraud Bureau (IFB) was launched. There was also clearly an agenda to move towards more 'deeper' policing, with the first head of the IFB a former police detective, John Beadle, with one of his opening statements, 'The Bureau is building powerful relationships with the police and law enforcement agencies.' Indeed, in the same launch statement the Deputy Director of the ABI stated, 'Insurers already stop a lot of fraud. Last year we detected fraudulent claims worth more than $f 400$ million. But the growth in organised fraud requires a new approach' (Aviva, 2006). The IFB has a staff of around 10, a $£ 1.7$ million budget and its members cover 95 per cent of the insurance industry. It operates the national cheatline for people to contact with suspected insurance fraud. One of its most important functions relates to the analysis of insurance claims of members using data mining and matching software. From this it identifies suspicious claims, which it then coordinates the investigation, the recovery of monies and pursuit of criminal prosecutions. Disruption is also an option pursued. The IFB in role, culture and orientation is very clearly rooted in a public 
police type organisation. It represents very clearly the 'deepening' of the industry policing of insurance fraud.

Figure 3 About here.

The gap in the IFB, however, was investigatory capacity, as it relies on the insurers own investigators and the police. Insurers are reluctant to commit resources to criminal investigations which are likely to require substantial funding, while the police, as this paper earlier revealed, have not had much interest in insurance fraud investigations. With the growing problem of insurance fraud and the lack of investigatory capacity it was therefore a natural step to look towards funding investigatory capacity. Insurers decided the best way to achieve this was to actually fund a police unit to pursue criminal prosecutions. The change in direction of insurers to more 'deeper' policing and the creation of the IFB exposed the gaps in taking forward criminal investigations. Financial pressures on the police, among other traditional factors associated with police disinterest in fraud investigation, meant this gap would not be addressed, unless the insurance industry funded a unit to do this. The substantial costs involved meant it took time for the insurers to reconcile this gap by securing commitment of funds. By 2012, however, this gap was resolved with the formation of the Insurance Fraud Enforcement Department (IFED) a privately funded police unit.

Industry funded police units and contributions to the funding of police investigations are not new (Gans, 2000). The Dedicated Cheque and Plastic Crime Unit and Police Vehicle Fraud Unit have been operating for some time funded by industry. Insurers concluded that the failure of the police to adequately deal with the problem of insurance fraud culminated in them funding a specialist police unit. In 2012 the Insurance Fraud Enforcement Department (IFED), based in the City of London police was founded. The unit has 34 detectives and financial investigators and has received a commitment for three years funding amounting to $£ 9$ million. IFED has a broader brief than 'crash-for-cash' fraud, covering all types of insurance fraud. In its first year it claimed to be investigating frauds amounting to over $\mathrm{f} 11$ million, achieved 260 arrests, 76 cautions and 12 convictions (IFED, 2013). This might not seem a great deal for the resources, but this is early days and it is likely the volume of criminal prosecutions for insurance fraud will increase and these will go beyond 'organised' crime groups. Evidence of prosecutions so far has shown many individual rather than group fraudsters been prosecuted, which in the past were less likely to have been.

Much of the private sector involvement in the policing of 'crash-for-cash' fraud might seem uncontroversial and appropriate -bar surveillance to which we will return later. Many of these frauds are straightforward to deal with in that they involve ordinary citizens rather than organised criminals and the aim of the investigation is to repudiate the claim, rather than prosecute. These cases rarely involve the criminal justice system, the arrest of a person or public exposure for the fraudster. The industry has simply developed appropriate measures to protect its interests and the question arises why should the public police with such scarce resources become involved in effectively protecting the bottom line of large corporations? Surely if the insurers want that service they should pay for it, which they now do. However, IFIG, IFED and IFB combined with some of the measures to be discussed represent a shift to 'deeper' policing which will extend the net of criminal prosecution beyond organised criminals to potentially anyone engaged in insurance fraud. These further 'deepening' measures will now be explored. 
Later in 2012 after the formation of IFED the next significant development occurred in the policing of insurance fraud with the creation of the Insurance Fraud Register (IFR). This is funded by the $A B I$ and operated by IFB. The register will include information on persons found to have made a fraudulent insurance claim or acted in some other way to facilitate insurance fraud. The criteria for placement on the register have not been published, but it will include many who have not been convicted in the criminal courts. This is similar to the databases CIFAS operate for largely the banking sector. Access to the IFR will only be for members. It marks the creation of the equivalent of the Violent and Sexual Offender Register for fraudsters. There will be significant implications for those placed upon it, as the statement launching it illustrated:

It is up to each individual insurer to decide how the information on the register is used; there is no common approach agreed across the industry; each insurer is at liberty to adopt its own approach. Insurers may wish to apply special terms to proven fraudsters, decline to accept them as new customers or decline to invite renewal of a product. Proven insurance fraudsters will find it harder to buy new products and to renew their existing products. They may also find it more difficult to obtain other financial services, including loans and mortgages (Out-Law.Com, 2012).

The IFR will clearly benefit insurers in identifying higher risk claims. The launch of the IFR also marks the creation of what could be described as a 'quasi-criminal sanction', outside the structures of the criminal justice system for the insurance industry, where placement and consequent punishment is decided by the private sector. The impact of this will be significant on those who are placed on the register in terms of securing insurance and their premiums if they are able to. The placement of those without a successful criminal prosecution and leaving the discretion to insurers is likely to concern some, as cases without the quality control of the criminal or civil justice system may slip through without appropriate evidence. Debates over the suitability of such a system are for another paper. However, the IFR represents another example of the 'deepening' of the private sector in the policing of insurance fraud, where private disputes over whether to pay a claim may also result in the placement of a name on a semi-public database which has consequences in a range of areas for the named.

So far the discussion on the 'deepening' involvement of the private sector in the policing of insurance fraud has focussed upon organisations and databases. This paper will now turn to other tools which are been used to target insurance fraud and particularly 'crash-for-cash' fraud.

\section{Unregulated surveillance}

The private sector makes great use of specialist firms offering surveillance services. These are largely orientated around 'directed surveillance' and to a lesser extent 'covert human intelligence sources' (CHIS) (rather than 'intrusive surveillance' which is restricted to certain public bodies under strict regulation and control). The CHIS in the private sector has largely been orientated around the infiltration of protest groups (Button and John, 2002). However, 'directed surveillance' is used extensively by many organisations and particularly in the private sector. It has, however, proved very controversial in relation to fraud in some cases, most notably when a council used staff to keep prospective school applicants under surveillance, to assess if they were lying about their address inorder to secure entrance for their children to a better school (BBC News, 2011). There have been further restrictions on parts of the public sector conducting 'directed surveillance' under the 
secondary legislation issued in 2010 under the Regulation of Investigatory Powers Act 2000. The use of surveillance by the insurance industry in the UK and elsewhere has been very common for some time (Reichman, 1987; Clarke, 1989). For 'crash-for-cash' fraud it is frequently used to observe those who have made personal injury claims. Investigators will follow claimants to assess if the description of their injuries and consequent restrictions, match their lifestyle. However, the regulatory controls the public sector face do not apply to the private sector. As one private investigator told the researchers:

For us, as a private organisation, RIPA does not apply because we follow individuals and there's a justifiable reason for that because it's been thought they have been exaggerating their injury, therefore, we're entitled to do that. As an organisation and, again, of being the largest surveillance company in the UK, we have a code of conduct that we've had for a number of years based on our own views as to what you can and what you can't do and the general views are that an English man's home is his castle, there should be no intrusive surveillance through windows, and the like, there should be no surveillance of children and things of that nature and we've effectively got our own code of conduct. There's nothing that says that we have to do that, but we've done that because that's just self preservation as a commercial organisation...

It could be argued where surveillance is being used to ultimately repudiate a claim, the justification for non-regulation is appropriate. However, when insurers are 'deepening' their engagement in policing and surveillance is used for quasi-criminal and criminal sanctions this changes the situation, something we will return to later in the paper.

\section{Prosecution through Contempt of Court}

Another example of the 'deepening' involvement of insurers is the use of Contempt of Court to pursue fraudsters. Under the Civil Procedure Rule 32.14 it provides that:

Proceedings for contempt of court may be brought against a person if he makes, or causes to be made, a false statement in a document verified by a statement of truth without an honest belief in its truth (Justice, n.d).

This is a civil form of Contempt, but is quasi-criminal in nature as the penalty is up to two years imprisonment and the burden of proof is to the criminal standard, beyond reasonable doubt. Any party to litigation, whether the claimant, defendant, witness, expert witness or lawyer runs the risk of this sanction if they deceive the court. Such cases are presided over in the High Court or County Court, depending upon the origin of the case without a jury. Obviously the fundamental prerequisite is that the alleged contemnor has engaged in a judicial process. Under CPR 32.14 proceedings may be brought only by the Attorney General or with the permission of the court. Civil litigants must ask the court for permission to bring committal proceedings for Contempt of Court.

The landmark case sparking this tool for insurers was Joanne Kirk v Carol Walton (2008). In this case Joanne Kirk claimed as a result of an accident in which her car experienced a rear end shunt had claimed it triggered health complaints leading her to give up work and the inability to walk more than ten yards. She had claimed for $£ 800,000$ and settled for $£ 25,000$. The insurers in this case, RBS, however, had commissioned private investigators to put her under surveillance and secured footage 
of her walking, shopping and driving. The insurers sought grounds to bring contempt proceedings against her on the grounds of 'making false statements'. The case was heard in March 2009 and she was found in contempt on two grounds of lying in court documents. Her penalty was to pay for her legal bill of $£ 125,000$, half the defendant's legal costs and a $£ 2500$ fine (Guildhall Chambers, n.d.).

There have been several other cases since this landmark case in 2009. In 2011 Acromas insurance brought a case of Contempt against Graham and Susan Loveday who had exaggerated claims of injury as a result of a crash. Their claims of disability unravelled when placing pictures of their caravan holiday on Facebook. In this case Mr Loveday was jailed for nine months and his wife was given a six months suspended sentence (Keoghs, 2011). Both of these cases were based upon exaggerated claims from real crashes. In 2012 the first case of Contempt was brought against a completely contrived accident. In Liverpool Victoria versus Bashir and others, Samina Bashir admitted making a false declaration for an accident which never occurred. She was given six weeks imprisonment along with her husband (which was reduced because they had a young child) with her parents also receiving a suspended prison sentence for their involvement. In addition they were ordered to pay $£ 17,000$ costs (Clyde and Co, 2012).

Many solicitors and investigation firms are now actively offering this tool to insurers. For example one legal firm DWF (2013) states this sanction:

As well as providing a remedy for fabricated incidents..., contempt proceedings are an ideal remedy for exaggerated claims, which currently fall outside the acceptance criteria for IFED, the specialist police unit dedicated to tackling insurance fraud.

It goes on to state,

The days when dishonest claimants who are found out can simply walk away from their actions are over. Procedures are in place to enable fraudsters to be punished and our experienced specialists are ready to use them. Delay is the enemy in this jurisdiction. The process is quick and relatively inexpensive and it is difficult to imagine a more potent counter fraud message to send fraudsters than they risk losing their freedom.

The development of this sanction does pose some interesting issues for debate. It provides for the potential for serious criminal penalties without some of the fundamental guarantees of criminal courts, such as trial by jury and access to legal aid to defend the action. The divisions between investigation and prosecution which occur in the criminal arena become blurred with Contempt too. Insurers effectively assume both roles as the client with the resources and ability to task their legal and investigation teams to pursue proceedings.

Nevertheless there is reason to consider this is an not unfair tool which is used to sidestep the guarantees of the criminal arena. In Bruce Samual Montgomery versus Carl Brown (2010) even where the claimant had been proved to have been lying, the case for Contempt was dismissed (Plexus Law, 2011). In Ramaraj v Ahmed (LTL 7/6/2012) the judge asked for his judgement to be prepared at public expense and delivered to the police for consideration for prosecution for fraud and conspiracy to pervert the course of justice, rather than pursue Contempt (1 Chancery Lane, 2012). 
The number of cases pursued in this category is not large. However, it does represent a significant development - in symbolism - of the private sector assuming a 'deeper' role in the pursuit of quasicriminal outcomes which does not involve the police, the Crown Prosecution Service or criminal courts, but which still can result in prison for the fraudster.

\section{Illegal and unethical tools}

The pursuit of illegal methods to gather information for newspapers by private investigators via 'hacking' and 'blagging' has been exposed by the Leveson (2012) inquiry and several other reports (Information Commissioners Office, 2006; SOCA, 2008). Less exposed has been the use of private investigators by numerous 'blue chip companies' in the insurance, financial services and legal sectors. The British quality newspaper the Independent has sought to expose this trade and argued:

British law enforcement and other government agencies have known for more than 12 years that sophisticated "blagging" tactics have been deployed by investigators commissioned by insurance firms, finance companies and solicitors.

They used the techniques to illicitly obtain private information by raiding official sources including the National Health Service, Customs \& Excise, Social Security, Royal Mail, high street banks, utility companies, credit card firms and councils (Independent, 2013).

Button (1998) has also found evidence in one case of a private investigator working for an insurance firm to investigate a man claiming loss of sex drive using a prostitute to proposition him. It is difficult to determine the extent to which such unethical and illegal tools are used by insurers, but there would seem to be evidence of some use. Combined with the other 'deepening' trends this also exposes the need for greater regulation, to which we shall return later.

\section{From the 'shallow' to the 'deep'}

Figure 4 below, brings together some of the changes in tactics used by insurers which have been taking place to illustrate the 'deepening' of the private sector in the policing of insurance fraud. Traditional repudiation of fraudulent claims resulting from the counter fraud capacity of insurers and their contractors with cross-sector databases for support have been supplemented with 'deepening' measures. These include intelligence sharing modelled on police best practice, the use of surveillance for cases which go beyond repudiation, combined with the use of quasi-criminal sanctions such as the IFR and the use of Contempt. The appetite for criminal prosecution has also increased with structures created to help better facilitate this with IFIG and the IFB. The 'deepening' involvement has implications, which will be considered in the final section.

Figure 4 about here.

\section{'Deeper' Policing and the Need for Greater Regulation}

This paper has illustrated the deepening involvement of insurers and their agents in the policing of insurance fraud, alongside also some evidence of unethical and illegal behaviour. There are also other sectors where there is evidence of such trends. For example in the financial services sector the funding of a police unit, the Dedicated Cheque and Plastic Crime Unit and Police Vehicle Fraud Unit, combined with the creation of CIFAS and their fraudster databases have illustrated another sector 
with deepening tendencies. In the media industry frauds against Virgin Media, combined with limited police interest, have led this company to not only pursue their own criminal investigation, but also their own private prosecutions (The Independent, 2011). Such approaches have also been pursued regularly by bodies dealing with copyright infringement relating to films and music through the Federation Against Copyright Theft (FACT) and the BPI (The British Recorded Musical Industry) (Button et al, 2012). It is therefore not just the insurance sector where reform is required, it is the wider private investigatory sector. This section, using the case of insurance fraud investigation will tease out some of the implications of these changes and what the response should be from policymakers. Central to this will be more effective regulation.

If the policing infra-structure of the insurance industry is orientated around repudiation of claims then the limited regulation of this sector would seem less contentious. However, the 'deeper' the private sector becomes in the policing of this fraud, the more controls to safeguard the public would seem to appropriate. As Stenning and Shearing (1979: 263) have argued vis-à-vis the private security industry in general:

If private security personnel are in reality no different from ordinary citizens, a law which treats them alike seems most appropriate. But if in reality they are not, and the law still treats them as they are, it becomes inappropriate...

The counter fraud investigative infra-structure is not acting like ordinary citizens or ordinary companies, it is 'deepening' its activities towards the criminal justice system and quasi-criminal sanctions, without any special controls. This requires further regulatory action.

When investigations can lead to criminal or quasi-criminal sanctions it is important that the investigators that conduct this work are fit and proper. It is essential they are of suitable character and are trained to minimum standards. The 2001 Private Security Industry Act provided for licensing of private investigators, but this has never been implemented, largely on the grounds of the difficulty of defining private investigators, which is strange given so many countries have regulated private investigators for some time (Button, 1998). The negative activities of some private investigators have been exposed regularly for some time (Younger, 1972; Button, 1998; Information Commissioners Office, 2006; SOCA, 2008; Leveson Inquiry, 2012; and Home Affairs Committee, 2012). In July 2013 the government announced the licensing of private investigators with plans to finally implement the provisions of the PSIA with minimum standards of training and character requirements, including bans for those found to have been involved in 'blagging' and 'hacking' (Home Office, 2013). This is a welcome step to addressing some of the gaps. However, there is one major concern with the proposals and that relates to in-house investigators. The Security Industry Authority (n.d.) website discussing the future of regulation makes the following statement:

Anyone involved in providing contracted private investigation services will require a licence. This includes employees, employers, managers, supervisors and directors or partners of private investigation companies. It is unclear if the Home Office will also wish us to regulate 'in-house' private investigations (authors emphasis).

If in-house are exempt this will only complete half the job. Those banned from a private investigator licence would still be able to legally work as in-house investigators and most importantly there would be no licence at stake for those in-house investigators who engaged in illegal or unethical 
behaviour. Licensing should apply to all those who work in investigations: in-house or contract. Clear complaints procedures should also be created for those working in this area equivalent to police investigators under the Independent Police Complaints Commission.

It also seems bizarre that there is public outrage and a political response to restrict surveillance as a consequence of a local authority checking if parents live where they say they do to secure a good school place, when there is no interest concerning the private sector conducting extensive surveillance with very few controls on a wide range of other activities (BBC, 2011). The lack of regulation of private surveillance is a major gap which needs to be filled. A code of conduct should be developed modelled upon public sector best practice which is a requirement for licensed investigative staff to comply with. Failure to do so should lead to the sanction of possible loss of licence as well as financial penalties for the employing organisation.

Penalties for those working in the private investigatory sector for breaching the law for the purposes of their work have been generally low. Indeed many data protection related crimes have no prison sentence and have a maximum fine of $f 5,000$. Indeed in one case an investigator running an illegal database of trade union activists, with over 3000 names on was fined $£ 5,000$ plus $£ 1,187$ costs (ICO, n.d). This was probably seen as a small cost of business for the culprit. In another case in 2005, Steve Whittamore was one of four men given a two-year conditional discharge at Blackfriars Crown Court in London after being convicted of breaching the Data Protection Act by selling confidential information to newspapers (Halliday, 2012). The most famous conviction to date of Glenn Mulcaire a private investigator arrested in August 2006 and subsequently convicted in 2007 for the part he allegedly played in hacking into the personal message boxes of mobile telephones (and, more specifically, for allegedly intercepting messages left for members of the Royal Household) and sentenced to six months' imprisonment. His contract with the News of the World was reported to be worth $f 100,000$ per year (Bowcott, 2011). Currently all of these are still free to work as private investigators and even when the new regulation is introduced, unless the in-house gap is addressed will be free to operate in this part of the sector.

Consideration should also be given to the greater regulation by the ICO of registers such as the IFR. The implications of placement on such a list have significantly more than for many other databases. Consideration should be given to national standards of what constitutes fraudulent behaviour to enable placement on such a list, clearer systems of appeal and controls on access to the data. The insurers clearly have a right to protect themselves from fraud by preventing and deterring fraudsters, but more needs to be done to ensure such systems are not abused and are used appropriately.

The use of Contempt of Court by insurers also raises issues which require further action. Given imprisonment is at stake, similar support should be given to defendants as would occur in a criminal case. If such measures become more popular there is also a debate to be had on whether such approaches should be restricted, given there is now a police unit funded to pursue criminal investigations.

\section{Conclusion}

The 'deepening' of private sector involvement in the policing of insurance fraud provides for some interesting experience in the context of greater private sector involvement in criminal investigation. 
The experience shows that an industry can develop an infra-structure to deal with crime. This can be both beyond the police and in partnership with them. It shows for the more organised criminal elements police involvement is crucial, but that when the problem hits a certain level of costs an industry is prepared to pay for the police. It shows that private sector involvement brings innovation, with the example of the emergence of quasi-criminal sanctions. Most significantly of all, however, it shows the capability of the private sector to provide and fund criminal investigations. Clearly there are potential concerns and a need for greater regulation in some areas. Indeed this paper has highlighted several areas in need of further statutory intervention. Finally given there has been growing interest in the privatisation of certain police functions, which includes investigation, it is worth examining what the experience from the insurance sector might offer to potential future police privatisation (The Guardian, 2012). The paper shows certain criminal investigations already occurring on a significant scale with little public controversy so far. Even with privatisation halted by some forces, such are the pressures in some sectors they may see privatisation re-emerge. Traditionally privatisation of the police has been one of gradual incremental steps in a variety of areas (Johnston, 1992; Jones and Newburn, 1998). It is therefore vital that regulation of such activities keeps up-to-date with the reality of what is occurring, not just for the insurance sector but the many other sectors which already or may see much greater private sector involvement in criminal investigation and the police who may have to increasingly resort to the private sector in criminal investigations as their budgets become ever tighter.

\section{Acknowledgements}

The authors would like to thank Chris Lewis and Azeem Aleem for their contribution to this research.

\section{Notes}

1. In February 2013 four men were jailed for their part in an attempted 'crash-for-cash' scam which resulted in the death of an innocent motorist Baljinder Kaur Gill. Miss Gill was the first person to die as a result of a deliberate crash. Many others have suffered injuries and traumas as a result of such scams (Huffington Post, 2013).

2. In the Spring of 2012 plans materialized for significant privatisation in England and Wales for the West Midlands and Surrey Police. The bid was reported to be worth $£ 1.5$ billion and was widely viewed as the first of many more. The potential work included a wide range of functions which could be provided by the private sector such as back office functions, incident response, patrol as well as investigation functions. For the latter in the tender document specified, 'Bring offenders to justice - investigate crimes, detain suspects, nonjudicial disposal, develop cases, support prosecution' (The Guardian, 2012). 


\section{References}

1 Chancery Lane., 2012. Personal Injury Briefing. Volume 5, No 3.

Association of British Insurers., 2013. Brace Yourself: UK is the Biggest Pain in the Neck in Europe [online]. Available from :

http://www.abi.org.uk/Media/Releases/2013/04/Brace yourself UK is the biggest pain in the neck in Europe .aspx [Accessed 26 April 2013].

Association of British Insurers., n.d. Submission to Fraud Review [online]. Available from:

http://www.abi.org.uk/Publications/24901.pdf [Accessed 26 April 2013].

Aviva (2006) Risk News. Bureau Launched to Tackle Insurance Fraud. Available from

http://www.aviva.co.uk/risksolutions/news/2006/07/28/bureau-launched-to-tackle-insurance-

fraud/ [Accessed $9^{t}$ January 2014].

BBC News., 2011. Poole council loses school catchment 'spying' tribunal [online]. Available from: http://www.bbc.co.uk/news/uk-england-dorset-10839104 [accessed 26 April 2013].

Bottoms, T., Gelsthorpe, L., and Rex, S., 2001. Community Penalties: Change and Challenges. Devon: Willan Publishing

Bowcott, O., 2011. hone hacking: Mulcaire must reveal who hired him in Coogan case. The Guardian [online]. Available from: http://www.guardian.co.uk/media/2011/feb/25/phone-hacking-casemulcaire-coogan [accessed 26 April 2013].

Brooks, G. and Button, M. The Police and Fraud Investigation and the Case for a Nationalised Solution in the United Kingdom. Police Journal, 84(4), 305-319.

Button, M., 2002. Private Policing. Cullompton: Willan Publishing.

Button, M., 1998. 'Beyond the Public Gaze' The Exclusion of Private Investigators from the British Debate Over Regulating Private Security. International Journal of the Sociology of Law, 26 (1), 1-16.

Button, M., Lewis, C., Shepherd, D., Brooks, G., and Wakefield, A. 2012. Fraud and Punishment: Enhancing Deterrence through More Effective Sanctions. Portsmouth: Centre for Counter Fraud Studies.

Button, M., John, T., 2002. 'Plural Policing' in action: a review of the policing of environmental protests in England and Wales. Policing and Society, 12(2), 111-121.

The Claims and Underwriting Exchange., n.d. What is CUE? [online]. Available from: http://www.insurancedatabases.co.uk/default.aspx [accessed 26 April 2013].

Clarke, M., 1989. Insurance Fraud. British Journal of Criminology, 29 (1), 1-20. 
Clyde and Co., 2012. Jail Time for Fraudsters in a Landmark Case [online].Available from: http://www.clydeco.com/uploads/Files/Publications/2012/Cc000864 Jail time for Fraudsters 14 03 12.pdf [accessed 30 April 2013].

Cohen, S., 1985. Visions of Social Control. Cambridge: Polity.

Crawford, A., 1998. Crime Prevention and Community Safety: Politics, Policies and Practices. London: Longman

Crawford, A., Lister, S., and Blackburn, S., 2005. Plural Policing: The Mixed Economy of Visible Patrols in England and Wales. Bristol: Policy Press.

Doig, A. and Levi, M. 2013. A Case of Arrested Development? Delivering the UK National Fraud Strategy within Competing Policing Policy Priorities. Public Money and Management, 33(1): 1-8.

DWF., 2013. Fraudsters Found Guilty of Contempt of Court and Sentenced to Imprisonment [online]. Available from: http://www.dwf.co.uk/insight/legal-updates/fraudsters-found-guilty-of-contemptof-court-and-sentenced-to-imprisonment [accessed 23 March 2013].

Dudley News., 2012. New West Midlands Police and Crime Commissioner Vows to End Police Privatisation [online]. Available from:

http://www.dudleynews.co.uk/news/10058997.New_West_Midlands_Police_and_Crime_Commissi oner_vows_to_stop_privatisation/ [accessed 30 March 2013].

Feeley, M. and Simon, J., 1994. Actuarial Justice: The Emerging New Criminal Law, in D. Nelken. ed. The Futures of Criminology. London: Sage

Gans, J., 2000. 'Privately Paid Public Policing: Law and Practice', Policing and Society, 10 (2), 183-206.

Garland, D., 1996. 'The Limits of Sovereign State: Strategies of Crime Control in Contemporary Society', British Journal of Criminology, 35 (4), 445-71.

Gill, M. and Hart, J., 1997. 'Exploring Investigative Policing', British Journal of Criminology, 37 (4), 549-567.

The Guardian,. 2013. Sixty Guilty in 'crash-for-cash' Scams [online]. Available from:

http://www.guardian.co.uk/uk/2013/mar/18/sixty-guilty-crash-cash-scam [accessed 12 April 2013].

The Guardian., 2012. Key Extract of Contract Note for Bidders for Police Services [online]. Available from: http://www.guardian.co.uk/uk/interactive/2012/mar/02/contract-note-bidders-policeservices [accessed 25 April 2013].

Guilhall Chambers., n.d. Conniving, Collusion and Contempt [online]. Available from: http://www.guildhallchambers.co.uk/uploads/docs/section9/ConnivingcollusioncontempJCB.pdf [accessed 29 April 2013]. 
Halliday, J. ,2012. Steve Whittamore's lucrative network of private information [online]. The Guardian.available from: http://www.guardian.co.uk/media/2012/mar/28/steve-whittamorenetwork-private-information [accessed 29 April 2013].

Holliday, I., 2000. 'Is the British State Hollowing Out?' The Political Quarterly, 71 (2), 167-76.

Home Office., 2013. New Regulation of Private Investigators to be Introduced [online]. Available from: https://www.gov.uk/government/news/new-regulation-of-private-investigators-to-beintroduced [accessed 27 August 2013].

House of Commons Home Affairs Committee., 2012. Private Investigators. Fourth Report of Session 2012-13. London: Stationery Office.

House of Commons Transport Committee., 2011. Cost of Motor Insurance: Follow Up. Twelfth Report of Session 2010-12. London: The Stationery Office.

Huffington Post (2013) Baljinder Kaur Gill Death: Gang Members Found Guilty Over 'Crash for Cash'. Available from http://www.huffingtonpost.co.uk/2013/01/10/baljinder-kaur-gill-

death n 2450991.html [accessed 8 January 2014].

Hughes, G. and Edwards, A., 2002. Crime Control and Community: The new politics of public safety. Devon: Willan publishing

Ilcan, S., and Basok, T. (2004) Community government: voluntary agencies, social justice, and the responsibilization of citizens. Citizenship Studies, 8 (2), 129-144.

Independent (2013) Exclusive: New blue-chip dirty tricks scandal revealed after 12 years of silence [online]. Available from: http://www.independent.co.uk/news/uk/crime/exclusive-new-bluechipdirty-tricks-scandal-revealed-after-12-years-of-silence-8721325.html [accessed 23 August 2013].

Independent (2011) Three Men Jailed Over Set Top Box Fraud. Available from http://www.independent.co.uk/news/uk/crime/three-men-jailed-over-settop-box-fraud2316116.html [Accessed 9 January 2014].

Insurance Fraud Bureau., 2013. 'Crash-for-cash' Putting the Brakes on Fraud. London: Insurance Fraud Bureau.

IFED., 2013. Annual Review 2012 [online]. London: City of London Police. Available from: http://www.cityoflondon.police.uk/NR/rdonlyres/06894EB0-EAAB-4FD5-844403CDE7866E3D/0/IFEDReviewWebversionfinal.pdf [accessed 29 April 2013]. Information Commissioners Office., n.d. The Consulting Association [online]. Available from: http://www.ico.org.uk/news/current topics/consulting association [accessed 29 April 2013].

Information Commissioners Office., 2006. What Price Privacy? [online] Available from: http://www.ico.org.uk/for the public/topic specific guides/ /media/documents/library/Corporate /Research and reports/WHAT PRICE PRIVACY.ashx [accessed 29 April 2013].

Jessop, B., 2004. 'Hollowing out the Nation-State and Multilevel Governance' in P. Kennett. ed. A Handbook Of Comparative Social Policy. Cheltenham: Edward Elgar 
Johnston, L., 1992. The Rebirth of Private Policing. London: Routledge.

Justice., n.d. Part 32 Evidence [online]. Available from http://www.justice.gov.uk/courts/procedurerules/civil/rules/part32\#IDA5SOHC [accessed on 29 April 2013].

Kemshall , H., 2008. Risks, rights and justice: Understanding and responding to youth risk. Youth Justice, $8(1), 21-37$.

Lister, S., Hobbs, D., Hall, S. and Winlow, S., 2000. Violence in the Night-Time Economy; Bouncers: The Reporting, Recording and Prosecution of Assaults, Policing and Society, 10 (4), 383-402.

Jones, T. and Newburn, T., 1998. Private Security and Public Policing. Oxford: Clarendon Press.

Keoghs., 2011. Client Alert - Stark Warning Given to Fraudsters [online]. Available from :

http://www.keoghs.co.uk/files/Client Alerts/2011/Client Alert - Loveday decision July 2011.pdf [accessed on 29 April 2013].

Livingstone, K and Hart, J., 2003. The Wrong Arm of the Law? Public Images of Private Security. Policing and Society, 13 (2), 159-70.

Leveson., 2012. An inquiry into the culture, practices and ethics of the press: report. Volumes 1 to 4. London: Stationery Office

Levi, M. and Maguire, M. 2012. Something old, something new; something not entirely blue: Uneven and shifting modes of crime control. In, T. Newburn and J. Peay (eds.) Policing: Politics, Culture and Control. Oxford: Hart Publishing. pp.195-218.

McLaughlin,E., Muncie, J., and Hughes, G., 2001. The Permanent Revolution: New Labour, New Public Management and the Modernization of Criminal Justice, Criminology and Penology, 1 (3), 301-318

Metropolitan Police Service (2011) Woman Sentenced for False claim. Available from http://content.met.police.uk/News/Woman-sentenced-for-falseclaim/1260269009336/1257246745756 [accessed 12 April 2012].

Morley, N. J., Ball, L. J. and Ormerod, T.C., 2006. How the Detection of Insurance Fraud Succeeds and Fails. Psychology, Crime and Law, 12(2), 163-180.

Motor Insurance Anti-Fraud and Theft Register., n.d. Welcome to MIAFTR2 [online]. Available from: http://www.miaftr-hpi.info/index.asp [accessed 29 April 2013].

Motor Insurers Bureau., n.d. Motor Insurance Database. Available from: http://www.mib.org.uk/Motor+Insurance+Database/en/default.htm [accessed 29 April 2013].

Out-Law.Com., 2012. Insurance Fraud Register Launched to Aid Crackdown on Fake Claims [online]. Available from: http://www.out-law.com/en/articles/2012/september/insurance-fraud-registerlaunched-to-aid-crackdown-on-fake-claims/ [accessed 29 April 2013]. 
Pearse, D., 2012. Police Federation Vice Chairman Says Privatisation Could Destroy Service [online]. The Guardian. Available from: http://www.guardian.co.uk/uk/2012/mar/03/police-federation-vicechairman-warning [accessed 29 April 2013].

Plexus Law., 2011. Contempt and the Required Criminal Standard - Bruce Samuel Montgomery v Carl Brown. Available from: http://cms.parabis.co.uk/repository/Plexus/Documents/E-Alert -

Contempt and the required criminal standard.pdf [accessed 29 April 2013].

Prenzler, T., 2006. Private Investigations, in M. Gill. ed. The Handbook of Security. Basingstoke: Palgrave.

Reichman, N., 1987. The Widening Webs of Surveillance: Private Police Unravelling Deceptive Claims, in C. Shearing and P. Stenning. Eds. Private Policing. Newbury Park: Sage.

Security Industry Authority (2013) Regulation of Private Investigators. Available from http://www.sia.homeoffice.gov.uk/Pages/licensing-private-investigations.aspx [accessed 9 January 2014].

Shearing, C., D. and Stenning, P., C. eds., 1987. Private Policing. Newbury Park: Sage.

Smith, G. and Button, M. and Johnston L., 2010. Studying Fraud as White Collar Crime. Basingstoke: Palgrave.

SOCA., 2008. Private Investigators: The Rogue Element of the Private Investigation Industry and Others Unlawfully Trading in Personal Data. London: SOCA.

Stenning, P., C. and Shearing, C., D., 1979. Private Security and Private Justice. British Journal of Law and Society. 6 (2), 261-271.

Wakefield, A. 2003. Selling Security - The Private Policing of Public Space. Cullompton: Willan.

Younger, K., 1972. Report on the Committee on Privacy. Cm 5012. London: HMSO. 
Figure 1. 'Shallow' to 'Deep' Policing

- Deviant acts dealt with between victim and offender without recourse
to official bodies
- Repudiation of claim, refusal of insurance cover, higher premiums etc
- Deviant acts referred to external body for official sanction
- Sharing of names of offenders, placement of name on register of
offenders, pursuit of civil justice and contempt of court.
- Deviant acts pursued for criminal prosecution.
- Criminal prosecution and measures to faciltate and expand criminal
prosecution.

Figure 2. Road casualties and personal injury claims compared

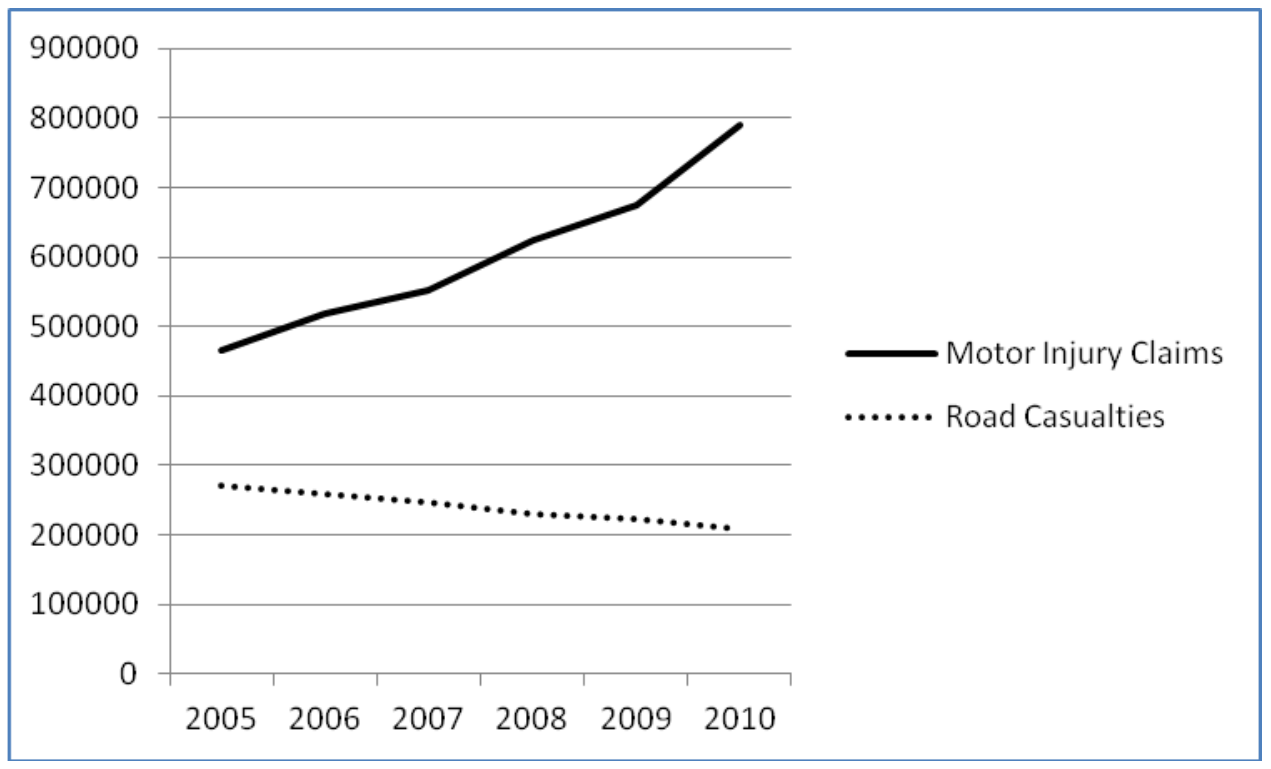

Note: Years for motor injury claims actually $2005 / 6$ etc and adapted for this graph. 
Figure 3. The deepening involvement of the private sector: policy responses to fraud

\begin{tabular}{|l|l|}
\hline 1994 & The Claims and Underwriting Exchange \\
\hline 1999 & Insurance Fraud Investigators Group (IFIG) \\
\hline 2006 & The Insurance Fraud Bureau (IFB) \\
\hline 2012 & The Insurance Fraud Enforcement Department (IFED) \\
\hline 2012 & Insurance Fraud Register (IFR) \\
\hline
\end{tabular}

Figure 4. The 'deepening' of private sector involvement in policing insurance fraud

\begin{tabular}{|c|c|}
\hline Depth & Tools and strategies \\
\hline Repudiation & $\begin{array}{l}\text { Investigation by insurers/contractors } \\
\text { Data-sharing and matching }\end{array}$ \\
\hline $\begin{array}{l}\text { Quasi-criminal } \\
\text { sanctions }\end{array}$ & $\begin{array}{l}\text { Intelligence sharing (IFIG) } \\
\text { Surveillance } \\
\text { Contempt of Court Prosecutions } \\
\text { Insurance Fraud Register }\end{array}$ \\
\hline $\begin{array}{l}\text { Criminal } \\
\text { prosecution }\end{array}$ & $\begin{array}{l}\text { Bodies to assist and pursue criminal } \\
\text { prosecution (IFIG/IFB/IFED) } \\
\text { Arrest and search } \\
\text { Criminal prosecution }\end{array}$ \\
\hline
\end{tabular}

